\title{
Evaluating of mechanical properties of (silicone/arabic gum/fish hask) composites used as pressure garment prosthetics
}

\author{
Noor Hadi Aysa ${ }^{1}$ \\ Clinical laboratory sciences department, College of pharmacy, University of Babylon
}

\begin{tabular}{ll}
\hline Article Info & ABSTRACT \\
\cline { 1 - 2 } & The mechanical properties of the silicone/ Arabic gum(oliban)/fish hask \\
& composites sheets as pressure garment for burn dressing material products \\
& were evaluated under compressive, tear resistance, and tensile loading \\
& conditions. Against a skin-like material, a silicone/ Arabic gum(oliban)/fish \\
Keyword: & husk composites garments had the highest antibacterial properties that \\
Silicone & isolate the injured skin from the outside polluted environment to prevent \\
tensile strength & infection besides that it help to improve the skin appearance by management \\
tearesistance & the scar growth. It spread the pressure above the large area of skin which \\
pressure garment & include healthy and injured that is will make injured skin to grow as same as \\
& normal neighbouring area.
\end{tabular}

Corresponding Author: Noor Hadi Aysa

Clinical laboratory sciences department, College of pharmacy, University of Babylon, Bablon,Iraq.

Official Email: phar.noor.hadi@uobabylon.edu.iq \& noorpharmacy83@gmail.com

\section{Introduction}

The interface between the injured skin and the environment is essential for fit and comfort [1],[2]. The interface is considered the most important aspect of the garment since an injured(with burn skin) will not wear even the most advanced garment if it is uncomfortable [3],[4], [5].This study investigates the applications of nanocomposites sheets prepared from silicone, oliban and fish shells as a novel material for garment burn dresses[6]. It has several remarkable properties that would address current issues with prosthetic materials [7], [8], [9]. The garments sheets used in this study are environmentally friendly and non-toxic[10]. However, only two reports comparing elastomeric garment sheets material properties have been published[11]. Compressive and shear/friction testing at quite high stress levels was conducted [12].

\section{The Material and Method}

The addition of the reinforcing materials( oliban, chitosan, fish husk) to the liquid silicone rubber effects on the biomechanical and physical properties of the sheets designed for the production of medical covers[13],[14] or compressive garments to minimize scars and improve the injured skin appearance[15],[16]. Chitosan, oliban and fish husk were added to the recipe at different rates (2, 4, 6, 8, 10 and 12\%) and studied the mechanical properties of the reciepe[17],[18].

Chitosan and oliban were then fixed at (6\%) because they gave good mechanical results, such as high tensile value and acceptable properties[19],[20]. These ratios were then used to test the resistance of the bacteria causing a number of diseases by measuring the size of the bactericide inhibitiing region.

\section{Results}

The structural properties are examined for the prepared chitosan as shown below. 
The structure of the chitosan was analyzed by the diffraction pattern and the diffraction angle. The size of the particles was examined using the electronic scanning microscope

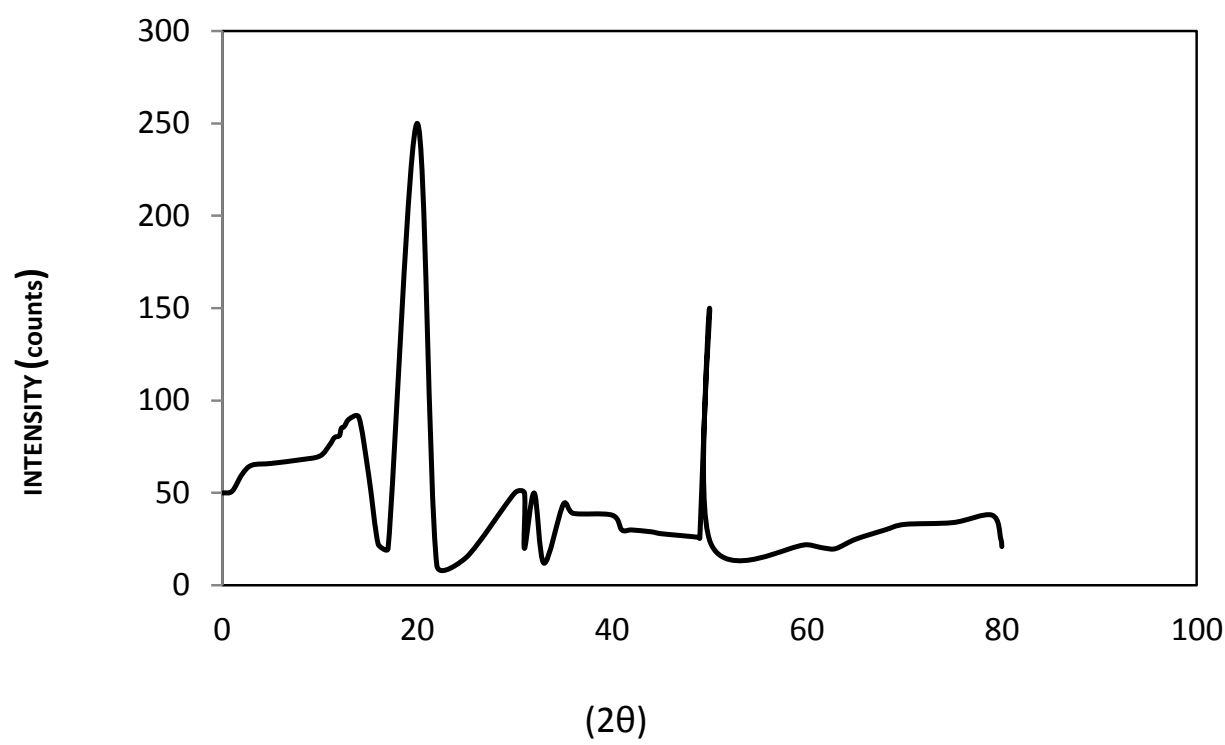

Figure 1. XRD for prepared chitosan

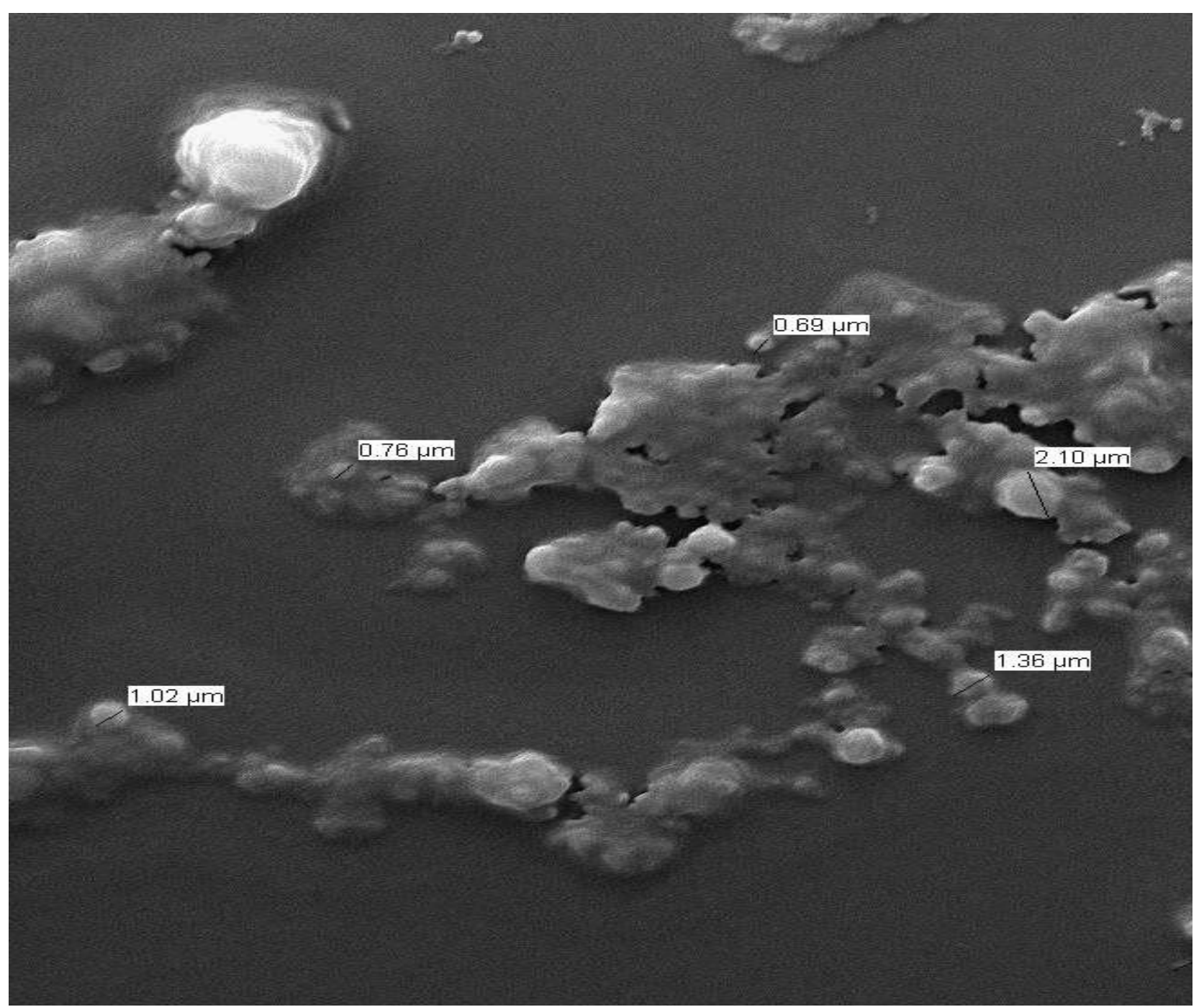

Figure 2. SEM test with grain size for prepared chitosan nanoparticles 
The chemical and structural properties were compared with the US standard specifications according to ASTM F2103-01[20] and showed a good correlation with the physical and chemical standard properties.

Effect of addition of chitosan and oliban/fish husk on the mechanical properties of polymeric material. Tensile strength Through fig. (3) we observe increased tensile strength. This is due to an increase in the interconnectivity between the chains of polymer and chitosan. It is noted that $6 \%$ gave the highest tensile value.

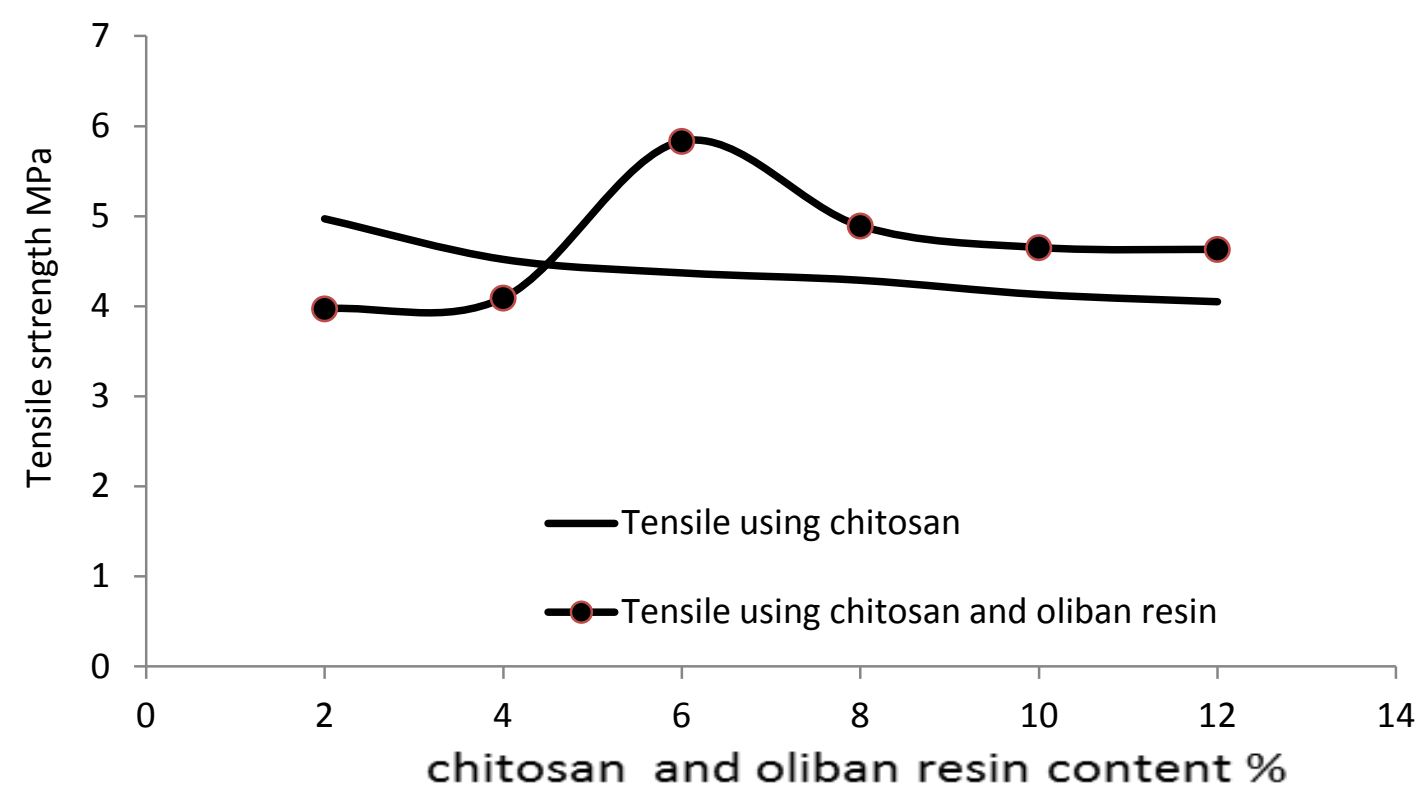

Figure 3. Effect of chitosan and oliban on tensile strength

\subsection{Tear resistance}

The resistance to rupture is influenced by the order of the chitosan and oliban particles on the polymer chains and therefore, the resistance to the rupture is enhanced by the homogeneous distribution of the molecules which increases their adhesion to each other.

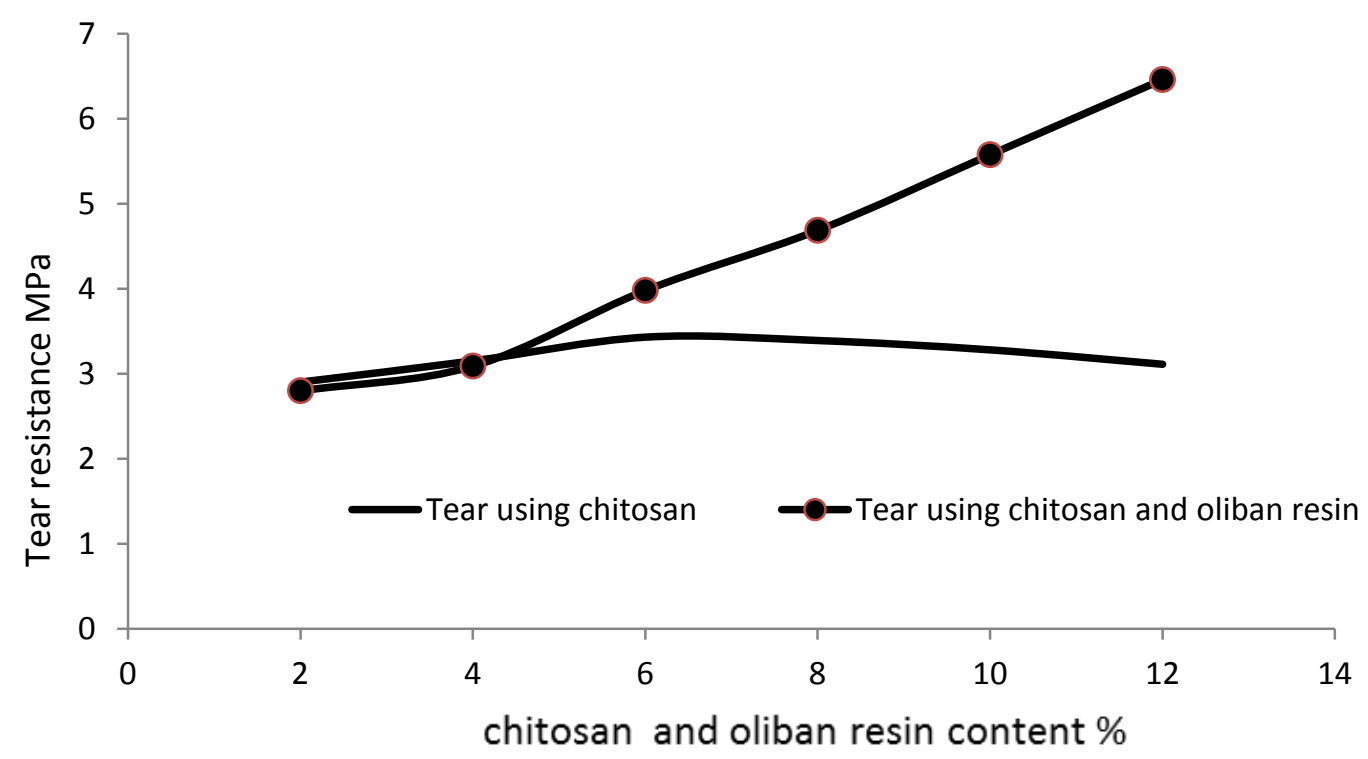

Figure 4. shows the effect of chitosan and oliban on the resistance to rupture 


\subsection{Compression}

The thickness of the kneading is reduced as the deformation is reduced by increasing the added ratios due to the increased hardness of the kneading and in turn reduces the compressibility when using heavy loads as shown in fig. (5).

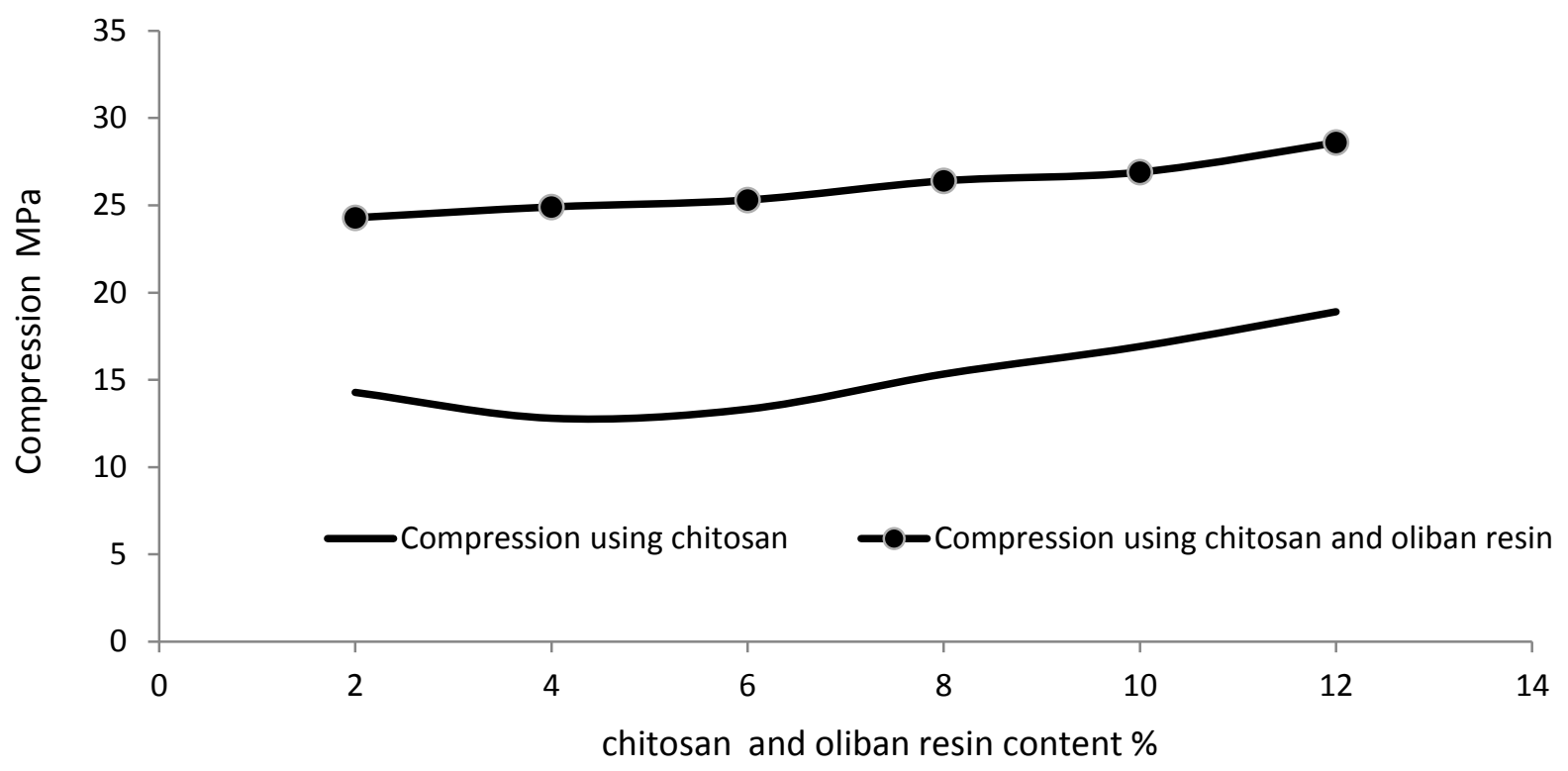

Figure 5. shows the effect of chitosan and oliban on compressibility

The results of bacterial growth for the best knead were obtained

As we used chitosan and oliban/fish husk, which is resistant to the growth of bacteria. We have transplanted species of bacteria that cause dermatitis known as PSYDOMONUS, STAPHYLOCCOCUS and other types of bacteria listed in the table 1 . The results of the transplant were shown in the laboratories of the faculty of Pharmacy, As a result of transplantation negative, which showed no growth of bacteria on the contrary, the additives have worked to kill the bacteria grown by measuring the diameter of the inhibition of bacterial growth (Inhibition Zone) when adding Chitosan and oliban/fish husk in their liquid and powder phases each separately and mixed with liquid and powder as declare in fig 9 . The results of the bacterial assays were summarized in the table below:

Table 1. The results of the antibacterial assays of different types of bacteria

\begin{tabular}{|c|c|c|}
\hline $\begin{array}{l}\text { Chitosan and oliban } \\
\text { preparations }\end{array}$ & Microorganisms & results/ conclusions \\
\hline Chitosan powder & $\begin{array}{l}\text { Escherichia coli, } \\
\text { Pseudomonas } \\
\text { aeruginosa, and } \\
\text { Staphylococcus. }\end{array}$ & Effective antimicrobial effect \\
\hline Oliban powder & $\begin{array}{l}\text { aureus, Staphylococcus } \\
\text { epidermidis, P. aeruginosa, } \\
\text { C. albicans and Aspergillus } \\
\text { niger }\end{array}$ & $\begin{array}{l}\text { Antifungal activity increase and } \\
\text { increasing masking of the protonated } \\
\text { amino groups with functional groups }\end{array}$ \\
\hline
\end{tabular}




\begin{tabular}{|l|l|l|}
\hline $\begin{array}{l}\text { Chitosan and oliban } \\
\text { preparations }\end{array}$ & Microorganisms & results/ conclusions \\
\hline Chitosan and oliban solution & $\begin{array}{l}\text { cherichia coli, Pseudomonas } \\
\text { aeruginosa, and } \\
\text { Staphylococcus }\end{array}$ & $\begin{array}{l}\text { Chitosan led to multiple changes in the } \\
\text { bacterial gene expression; binding of } \\
\text { chitosan to teichoic acid led to death of } \\
\text { bacteria }\end{array}$ \\
\hline
\end{tabular}
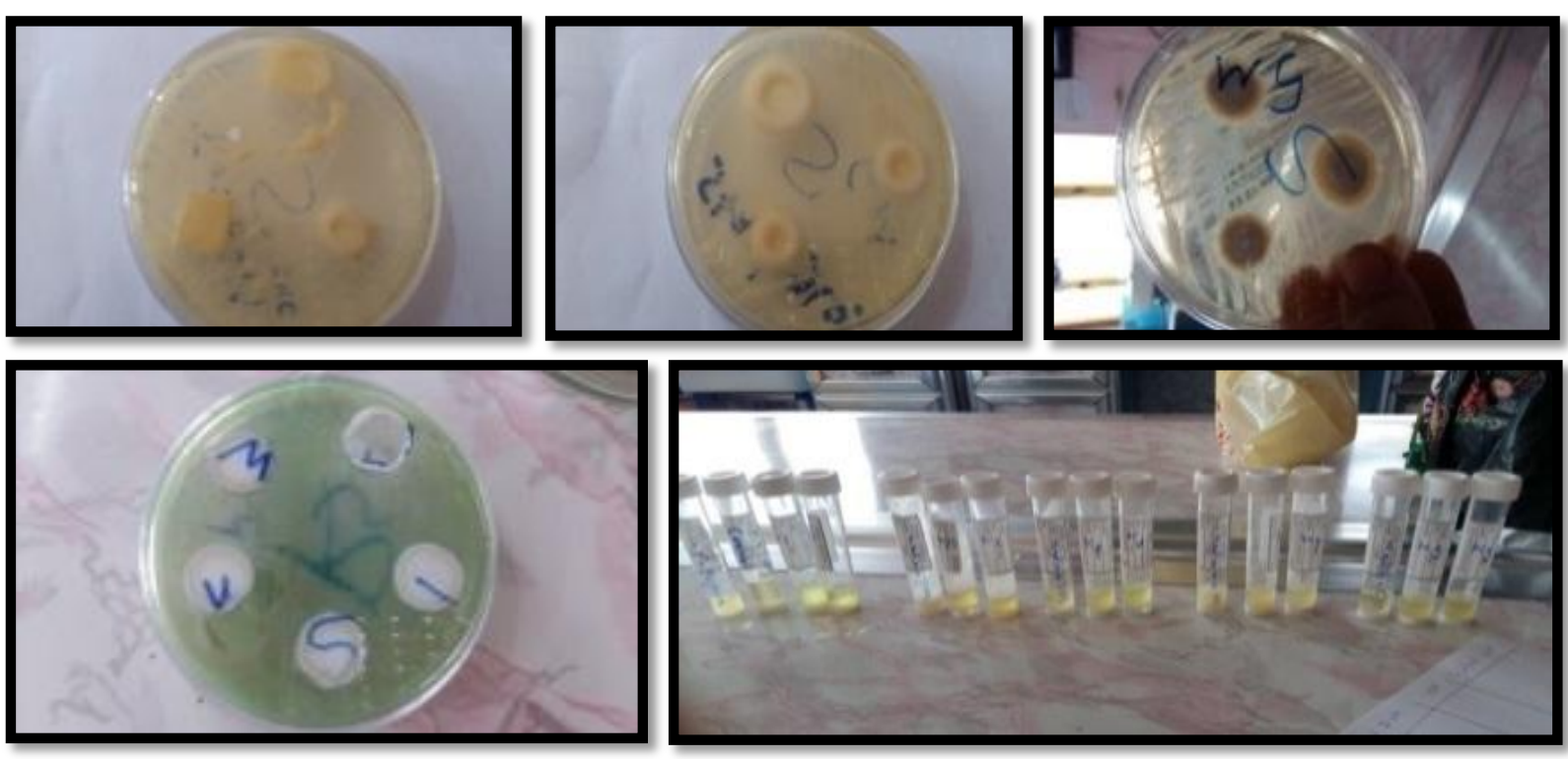

Figure 9. Results of the bacterial implantation of the two oliban and chitosan in the two phases of liquid and powder and more than a type of bacteria

\section{Discussion and Conclusions}

The above table shows the high efficacy of the prepared material with the possibility of industrial use in the medical field to match the bacterial tests with the association for the Advancement of Medical Instrumentation (AAMI) standards and international standards, [13]. The mechanism of action of chitosan recorded in the structure of the bacteria measured above is shown by the presence of charged groups in the structure column of the (chitosan), which carries a positive charge and ionic interactions with the components of the bacterial wall (which is negatively charged). This interaction indicates the hydrolysis of peptidoglycans in the wall of microorganisms, triggering leakage of intracellular electrolytes, leading to the death of microorganisms. The study of the mechanical properties, which requires the strength of tension, rupture and compressive appropriate to provide a suitable environment for skin growth in the affected area naturally undamaged because the body works to increase blood perfusion as an attempt to repair the injured skin without being controlled growth, distinct from the surface of the skin here, the compression of the pressure sheets is important as it restricts blood flow to the scar area and thus inhibits the growth and enlargement of the scar as well as control collagen synthesis by reducing the supply of blood, oxygen and nutrients. This requires wearing them for a certain period of time, which requires good mechanical properties to allow them to be worn and left on a daily basis without losing their elasticity and compressibility. As for the materials used, it is known medically that it does not cause any sensitivity to the body as natural polymers represented by Chitosan and oliban, known for their medicinal uses and on a large scale as anti-growth of bacteria and fungi[22],[23]. The effectiveness of silicone sheets supported by chitosan and oliban is the increase in elasticity and durability and the potential increase in the levels of moisture in the scars area, isolation from the air bacteria and raise the temperature and increase pressure on the scar, which improves the color of the skin according to size and depth of infection and skin thickness and color. It is also possible to use silicone composites prepared today in many life-saving medical devices such as pacemaker and also in many pharmaceutical applications such as pharmaceutical manufacturing pipes. As mentioned above, we conclude 
that the prepared polymeric sheets do not cause any sensitivity or inflammation caused by the growth of bacteria and entering the bloodstream in the humid circles, which is a center for the growth of bacteria . The possibility of preparing the rubber kneading used in the manufacture of anti-bacterial covers and dressings, which helps in the healing of wounds and accelerate the reduction of scars and therefore the process of manufacturing them will be inexpensive because they are available locally. Mechanical characteristics of tensile strength and tear resistance are compatible with the shape of the member to suit the permissible stress, especially at stress concentration points.

\section{References}

[1] Peters, Hemptenmacher, Kumpfert and Leyens(2003)," In: Titanium and Titanium Alloys", edited by Christoph Leyens and Manfred Peters, Wiley-VCH,Germany, p. 1

[2] Boutwell, MS; Rebecca Stine, MS; Andrew Hansen, PhD; Kerice Tucker, BS; Steven Gard, (2012), "Effect of prosthetic gel liner thickness on gait biomechanics and pressure distribution within the transtibial socket", JRRD Volume 49, Number 2, P. 227-240.

[3] Werner, Van Zyl, G. Monserrat,(2002), "Hybrid Polyamide/Silica Nanocomposites: Synthesis and Mechanical Testing", Macromolecular Materials and Engineering, P. 106-110.

[4] Rasha Hadi Saleh, Nada Khazal Kadhim Hindi, Mohammed R. Abid Ali, (2017), " Antibacterial Activity of Aquatic Zea Mays L. Hairs Extract against Different Bacteria in Babylon Province: An In-Vitro Study", Journal of Global Pharma Technology, ISSN 0975 -8542

[5] Thomas S., Stephen R., (2010), "Rubber nanocomposites: preparation, properties, and applications",ISBN 978-0-470-82345-3, India.

[6] Jorgen S. B., C. B. Mary,(1999), "Mechanical behavior of particle filled elastomers", Rubber Chem. Technol., Vol. 72, P. 633-656.

[7] Chen Q., Sh. Liang, G. A. Thouas, (2013),"Elastomeric Biomaterials for Tissue Engineering Progress", Polymer Sciencev, vol 38 (3-4), p. $584-671$.

[8] Noor Hadi Aysa, Halah Dawood Salman, "(2016)," Antibacterial activity of modified zinc oxide nanoparticles against Pseudomonas aeruginosa isolates of burn infections" WSN, vol. 33 1-14 EISSN 2392-2192

[9] HE Meulenbelt, JH Geertzen, MF Jonkman, PU.Dijkstra,(2011), "Skin problems of the stump in lower limb amputees: A clinical study", Acta Derm Venereol, vol. 91(2), P.173-77

[10] Noor H. Aysa, Mohammed H. AlMaamori, and Nehad A. Al Maamori,(2015), "Studying the mechanical properties of silicone rubber-alum composites using in manufacturing of prosthetic liners", Journal of Natural Science Research, ,ISSN (Paper) ISSN (Paper) 2224- 3186 ISSN (Online), 2225-0921.

[11] Noor H. Aysa, Mohammed H. AlMaamori, and Nehad A. Al Maamori,(2015)," Effect of the unmodified and modified $\mathrm{ZnO}$ nanoparticles on the mechanical and antibacterial properties of silicone rubber using in medical applications", Journal of Nanoscience and Nanoengineering,Vol. 1, No. 3, p. 119124.

[12] Standard Guide for Characterization and Testing of Chitosan Salts as Starting Materials Intended for Use in Biomedical and TissueEngineered Medical Product Applications, Annual Book of ASTM Standards, Vol 06.01. 3

[13] AAMI/ISO 14160-1998 Sterilization of Single-Use Medical Devices Incorporating Materials of Animal Origin - Validation and Routine Control of Sterilization by Liquid Chemical Sterilants.

[14] Amal Talib Al-Saady; Habeeb Sahib Naher,(2018), "study of routs of etiologicbacteria causing neonatal infections in Al-Hilla city, Iraq", Biochem. Cell. Arch.Vol.18, No.1, pp. 577-586.

[15] SA Morsi, W M Moslem, SK El- Labany(2019), " Interpretation of localized surface nano-structures", Periodicals of Engineering and Natural Sciences ISSN 2303-4521, Vol.7, No.2,pp.881-887

[16] Partha Pratim Sengupta,Madhabendra Sinha, Ujjal Protim Dutta (2019) Economic and environmental performances in manufacturing industries: A comparative study, Periodicals of Engineering and Natural Sciences ISSN 2303-4521Vol.7 No. 1, pp.99-108. 
[17] Becker, R., \& Henderson, V. (2000). Effects of air quality regulations on polluting industries. Journal of Political Economy, 108(2), 379-421.

[18] Vitala H R , B P Dileep , A.Megalingam ,Karthik K,(2018)" Mechanical and Tribological Characterization Nitrided Al-7075/A12O3 Metal Matrix Composites ", Periodicals of Engineering and Natural Scinces ISSN 2303-4521, Vol.6, No.2, pp.64-70.

[19] E. Akca and A. Gursel,(2015) "A Review on Superalloys and IN718 Nickel-Based INCONEL Superalloy," Periodicals of Engineering and Natural Sciences, vol. 3, pp. 15-27.

[20] Gokhan Y1ldiz, Ali Gursel , Enes Akca,(2017)" Effects of Cooling Rate on Strength and Microstructure of Powder Metallurgy Superalloys",Periodicals of Engineering and Natural Sciences, Vol.5, No.3,pp.251-255.

[21] Ömer Yavuz Bozkurt, Özkan Özbek, Atban Rafea Abdo,(2017)" The Effects of Nanosilica on Charpy Impact Behavior of Glass/Epoxy Fiber Reinforced Composite Laminates",Periodicals of Engineering and Natural Scinces, Vol.5, No.3,pp.322-327.

[22] J. K. Pandey, K. R. Reddy, A. K. Mohanty, M. Misra, "Handbook of Polymer nanocomposites. Processing, Performance and Application Volume A: Layered Silicates," Germany: Springer-Verlag Berlin Heidelberg, 2014.

[23] P. Rosso, L. Ye, S. Sprenger, “A toughened epoxy resin by silica nanoparticle reinforcement," Journal of Applied Polymer Science, 100(3), pp. 1849-1855, 2006 